\title{
Implementasi Sistem Pelacakan Kendaraan Bermotor Menggunakan Gps Dan Gprs Dengan Integrasi Googlemap
}

\author{
Y. Dul Muchlisin dan J. Eko Istiyanto
}

\begin{abstract}
Vehicle tracking system using GPS and GPRS integration googlemap provide information that is maximized with the technology of GPS (Global Positioning System) receiver which can indicate the position of the vehicle with the map and the ability of the appointment of direction and position coordinates ( $x$, y or latitude, longitude) textually and visual at any location. Vehicle tracking system is built using equipment GIS (Geographic Information System) and dedicated to smartphones which support Global Positioning System (GPS), as well as portable computers, using General Packet Radio Service (GPRS) as a connection to the internet. The hardware used is a smartphone that supports GPS with supporting tools used are GoogleMaps, Notepad + +, NetBeans IDE 6.5.1, Mysql, Java (J2ME), PHP, JavaScript.

The results of this system in the form of tracking system capable of monitoring the movement of vehicles on an ongoing position by utilizing GPS and GPRS as the sender of the wireless data and Internet connections.
\end{abstract} $J 2 M E$,

Keywords- GIS, GPS, GPRS, googlemaps,

\section{PENDAHULUAN}

$S_{p=0}^{c}$ eiring dengan perkembangan zaman dan perekonomian di dunia peningkatan jumlah kendaraan bermotor yang sangat signifikan dewasa ini berpotensi menimbulkan ketidakteraturan, pelanggaran rambu lalulintas, pelanggaran jalur kendaraan, dan pencurian kendaraan, baik kendaraan yang sedang bergerak maupun yang sedang diparkir, untuk kelancaran, keamanan dan manajemen target yang bergerak seperti mobil, truk, bus, pesawat terbang dan sebagainya, diperlukan suatu sistem pengontrolan dan pengawasan objek bergerak dari tempat lain melalui jalur komunikasi jarak jauh, seperti tracking armada taksi, tracking untuk jasa rental mobil, tracking untuk truk pengangkut sembako,

Yazid Dul Muchlisin , Mahasiswa S2 Ilmu Komputer UGM, email: yazid.bcom@gmail.com

Jazi Eko Istiyanto, staf pengajar Jurusan Ilmu Komputer dan Elektronika dan Ketua Jurusan Fisika, FMIPA UGM, Kantor: FMIPA-UGM, website: http://jazi.staff.ugm.ac.id, e-mail: jazi@ugm.ac.id. tracking untuk jalur kereta api, tracking untuk jalur pesawat terbang (airplane tracking) dan sebagainya, merupakan objek serta target yang perlu diawasi dan dimonitor supaya berjalan sebagaimana mestinya.

Hal ini penting, karena pihak yang mempunyai objek bergerak yaitu kendaraan bermotor tidak bisa mengontrol dan mengawasi sendiri, apalagi biaya masih relatif mahal, khususnya pada biaya transfer data posisi. Pendekatan teknologi pada kondisi ini dapat dipenuhi dengan adanya sistem pelacakan kendaraan bermotor yang merupakan salah satu dari sekian banyak jenis teknologi informasi yang berkembang dewasa ini.

Dalam hal ini, diperlukan sebuah teknologi yang dapat membantu dalam memonitoring secara terus menerus pergerakan kendaraan (fleet management system) yang dapat dipantau dari jarak jauh yang berbasis sistem pelacakan kendaraan bermotor secara real time.

\section{Metode Penelitian}

Penyusunan penelitian ini menggunakan teknik antara lain:

1. Studi Literatur

Mengumpulkan informasi dari website di internet sebagai bahan referensi untuk menunjang penyusunan penelitian ini.

2. Metode Pengembangan sistem yang meliputi analisis, desain, implementasi. Pembuatan aplikasi ini menggunakan perangkat lunak dan perangkat keras yaitu:
a. Google map
b. Smartphone yang support GPS
c. Java (J2ME)
d. JavaScript
e. Notepad++
f. PHP
g. Mysql
h. NetBeans IDE 6.5.1

\subsection{Konsep mobile GIS (Geographical Information System)}

Perubahan penggunaan informasi geografis salah satunya disebabkan oleh perkembangan teknologi informasi berupa perubahan dari GIS 
berbasis komputer di kantor ke tangan pengguna. Kombinasi mobilitas, koneksi tanpa kabel, dan fungsionalitas dasar GIS, yaitu penyimpanan, pencarian kembali, analisis, dan penampilan data kartografi yang membentuk suatu sistem mobile GIS, memungkinkan pencarian informasi di manapun dan kapanpun [1].

Mobile GIS merupakan integrasi antara tiga teknologi, yaitu perangkat lunak GIS, teknologi Global Positioning System (GPS), dan perangkat alat komunikasi genggam. Teknologi tersebut membuat basis data yang dapat diakses oleh personil di lapangan secara langsung di segala tempat dan waktu. Sistem ini dapat menambah informasi secara real-time ke basis data dan aplikasinya dalam hal kecepatan akses, tampilan, dan penentuan keputusan [1].

Mobile GIS adalah perpaduan dari teknologi GIS, Mobile hardware dengan perangkat lunaknya, Global Positioniong System (GPS) dan komunikasi wireless untuk akses ke internet GIS. Mobile GIS menawarkan fleksibilitas yang besar, memungkinkan pengguna memperoleh hasil secara cepat sesuai dengan kebutuhan mereka. Mobile GIS menyediakan akses data dari segala tempat dan di kapanpun keberadaan pengguna.

Adapun beberapa komponen yang bergabung membentu mobile GIS, yaitu mobile client, jaringan tanpa kabel, dan server. Mobile client berupa perekam data posisi misalnya GPS, yang mana pergerakan mobile dengan GPS yang diperoleh dan dengan GSM dapat mengirimkan posisi geografis ke server melalui Short Message Service (SMS) atau dalam kondisi lain dimana orang yang membawa PDA yang di dalamnya sudah terinstal Palm OS atau Windows CE dengan dilengkapi GPS. PDA tersebut dapat menunjukkan peta digital beserta koordinatnya dengan mengkomunikasikan dengan server melalui jaringan tanpa kabel. Jaringan tersebut dapat melalui Global System for Mobile Communication (GSM), General Pocket Radio System (GPRS), Code Division Multiple Access (CDMA) yang mendukung transmisi digital [2].

\subsection{Global Positioning System (GPS)}

GPS merupakan sistem navigasi satelit yang dikembangkan oleh Departemen Pertahanan Amerika Serikat untuk keperluan sipil dan militer dalam hal penentuan posisi tiga dimensi. Sistem ini untuk mendapatkan posisi secara cepat dan tepat. GPS dapat digunakan dalam pengukuran di segala jenis cuaca pada siang atau malam hari. GPS terdiri dari tiga segmen utama yaitu segmen angkasa yang terdiri dari satelit-satelit GPS, segmen sistem kontrol yang terdiri dari stasiun monitor dan kontrol satelit yang tersebar di seluruh permukaan bumi, dan segmen pemakai yang terdiri dari pengguna di darat,udara ataupun laut [3].

Pada pengamatan posisi dengan GPS, setiap satelit akan memancarkan sinyal atau gelombang GPS dan akan diterima oleh receiver. Satelit GPS memancarkan sinyal secara terus menerus yang berisi informasi kepada pengguna tentang posisi satelit yang bersangkutan yang dapat digunakan untuk menentukan jarak satelit ke pengamat. Dengan mengamati sinyal satelit dalam jumlah dan waktu yang cukup, pengamat dapat menentukan posisinya. Dari wilayah Indonesia umumnya enam sampai sembilan satelit GPS akan bisa ditangkap dengan sudut elevasi diatas 100. Satelit GPS memiliki 27 satelit yang mengorbit pada 6 bidang orbit yang berbeda dimana periode orbitnya selama 12 jam, kecepatan $3,87 \mathrm{~km} /$ detik, setengah sumbu orbit $26.660 \mathrm{~km}$, inklinasi 55o dan jarak rata-rata dari kulit bumi model global (WGS'84) ke setiap satelit adalah $20.200 \mathrm{~km}$. Sudut pandang dari satelit terhadap permukaan bumi sebesar 270. GPS menggunakan sistem pengukuran one way ranging. Sinyal GPS yang baru terdiri dari tujuh kode sinyal yaitu L1 C/A, L1 P(Y), L1M, L2C, L2 P(Y), L2 M, L5C. Blok satelit II memiliki 8 satelit, blok II-A memiliki 18 satelit, dan blok IIR memiliki 1 satelit. Beberapa blok satelit yang baru diluncurkan antara lain blok satelit IIR-M pada tahun 2003 dan IIF pada tahun 2005 [4].

\subsection{Segmen Kontrol}

Segmen kontrol dari Global Positioning System terdiri dari satu Master Control Station (MCS) yang terletak di Falcon Air Force Base di Colorado Springs, Colorado, dan lima stasiun monitor yang terletak strategis di seluruh dunia. Selain itu, Angkatan Udara mempertahankan tiga primer tanah antena, terletak kurang lebih berjarak sama di sekitar khatulistiwa. Dalam hal beberapa kegagalan katastropik, ada juga dua cadangan Master Control Stasiun, satu yang terletak di Sunnyvale, California, dan lain di Rockville, Maryland.

Stasiun monitor pasif melacak semua satelit GPS terlihat oleh setelit pada setiap saat, mengumpulkan sinyal data dari masing-masing. Informasi ini kemudian diteruskan ke Master Control Station pada Colorado Springs melalui DSCS aman (Pertahanan Satelit Komunikasi System) dimana posisi satelit ("ephemeris") dan 
data jam-waktu diperkirakan dan diprediksi. Master Stasiun Kontrol kemudian secara berkala mengirimkan koreksi/pengecekan posisi dan data jam-waktu ke antenna/pemancar yang sesuai yang kemudian meng-upload data tersebut ke setiap satelit. Kemudian satelit mengkoreksi informasi pada pengiriman data sampai ke pengguna. Urutan peristiwa ini terjadi setiap beberapa jam untuk masing-masing satelit untuk membantu memastikan bahwa setiap kemungkinan kesalahan pada posisi atau jam bisa diminimalkan. Seperti pada Gambar 1 [5].

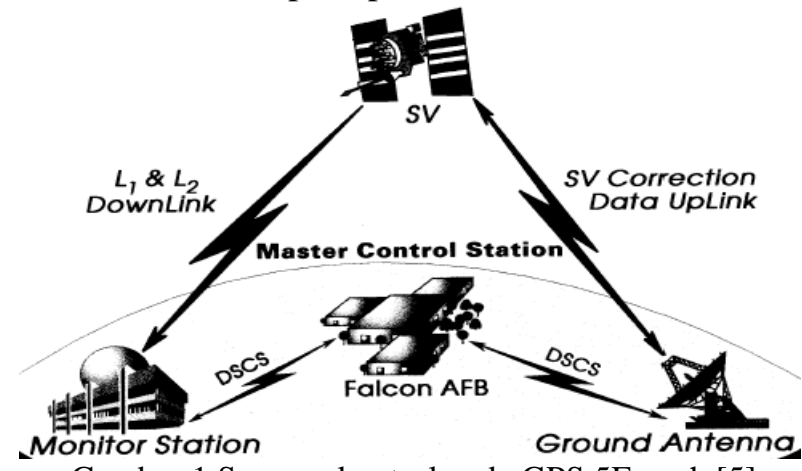

Gambar 1 Segmen kontrol pada GPS 5French [5].

\subsection{GPRS}

GPRS menyediakan paket layanan GSM untuk transmisi data dengan model paket dalam sebuah PLMN. Model paket- switched, tidak ada sambungan permanen yang dibentuk antara selular dan jaringan eksternal selama transfer data. Sebaliknya, dalam mode circuit-switched, sambungan dibentuk selama jangka waktu transfer antar entitas panggilan dan entitas yang disebut. Dalam paket-mode switched, data ditransfer dalam blok data, yang disebut paket. Ketika transmisi paket yang dibutuhkan, saluran radio sudah dialokasikan, namun dilepaskan segera setelah. Metode ini meningkatkan kapasitas jaringan. Memang, beberapa pengguna dapat berbagi saluran yang diberikan, karena tidak dialokasikan untuk single user dalam suatu periode panggilan keseluruhan.

Salah satu tujuan utama dari GPRS adalah untuk memfasilitasi interkoneksi antara ponsel dan paket lain-jaringan diaktifkan, yang membuka pintu ke dunia Internet. Dengan diperkenalkannya mode paket, telepon seluler dan bertemu Internet untuk menjadi teknologi mobile Internet. Teknologi ini diperkenalkan di telepon seluler memungkinkan pengguna untuk memiliki akses ke layanan bernilai tambah baru, termasuk:

1. Client-server layanan, yang memungkinkan akses ke data yang disimpan dalam database. Contoh yang paling terkenal ini adalah akses ke World Wide Web (WWW) melalui browser.

2. Layanan olahpesan, dimaksudkan untuk komunikasi user-to-user antara pengguna individu melalui server penyimpanan untuk penanganan pesan. Multimedia Messaging Service (MMS) adalah contoh dari aplikasi messaging terkenal.

3. Real-time layanan percakapan, yang menyediakan komunikasi dua arah secara real-time. Sejumlah aplikasi Internet dan multimedia membutuhkan skema ini seperti voice over IP dan video conferencing.

4. Tele-tindakan jasa, yang ditandai dengan transaksi pendek dan diperlukan untuk layanan seperti SMS, pemantauan elektronik, sistem pengawasan, dan transaksi undian.

GPRS memungkinkan untuk optimalisasi sumber daya radio dengan menggunakan packet switching untuk aplikasi data yang dapat menyajikan karakteristik transmisi sebagai berikut:

a. Jarang transmisi data, seperti ketika waktu antara dua transmisi melebihi rata- rata keterlambatan transfer (misalnya, layanan pesan).

b. Sering transmisi blok data kecil, dalam proses beberapa transaksi kurang dari 500 oktet per menit (misalnya, men-download beberapa halaman HTML dari aplikasi browsing).

c. Jarang blok transmisi data yang lebih besar, dalam proses beberapa transaksi per jam (misalnya, akses informasi yang tersimpan di pusat-pusat database);

d. Asimetris throughput antara uplink dan downlink, seperti untuk pengambilan data pada server di mana uplink digunakan untuk mengirimkan perintah sinyal dan downlink digunakan untuk menerima data sebagai respon dari permintaan (misalnya, WEB / WAP browser).

Sebagai operator GPRS mengoptimalkan sumber daya radio dengan berbagi mereka antara beberapa pengguna, ia mampu mengusulkan biaya lebih menarik untuk transmisi data dalam mode GPRS daripada di circuit-switched mode. Memang, faktur dalam circuit-switched mode memperhitungkan waktu koneksi antara pengguna menelepon dan pengguna menelepon. bahwa transmisi data dipertukarkan dari ujung ke ujung selama $20 \%$ dari waktu koneksi circuitswitched. Sebagai contoh, pengguna WWW, download sebuah halaman HTML diidentifikasi dengan uniform resource locator (URL), 
membaca isi dari halaman HTML, kemudian download sebuah halaman HTML baru untuk membaca. Dalam contoh ini tidak ada data yang dipertukarkan dari ujung ke ujung antara dua download halaman HTML. Untuk jenis aplikasi, suatu faktur yang lebih tepat akan memperhitungkan volume pertukaran data bukan waktu koneksi circuit-switched. Dalam mode paket, pengguna GPRS dapat dikenakan tagihan sesuai dengan jenis layanan yang diminta, volume data yang dipertukarkan [6].

\subsubsection{Arsitektur jaringan GSM}

Struktur jaringan GSM bergantung pada beberapa entitas fungsional, yang telah ditetapkan dalam hal fungsi dan interface. Ini melibatkan tiga subsistem utama, masing-masing unit fungsional yang mengandung dan saling berhubungan dengan orang lain melalui serangkaian interface standar. Bagian-bagian utama dari jaringan GSM, seperti pada Gambar 2.

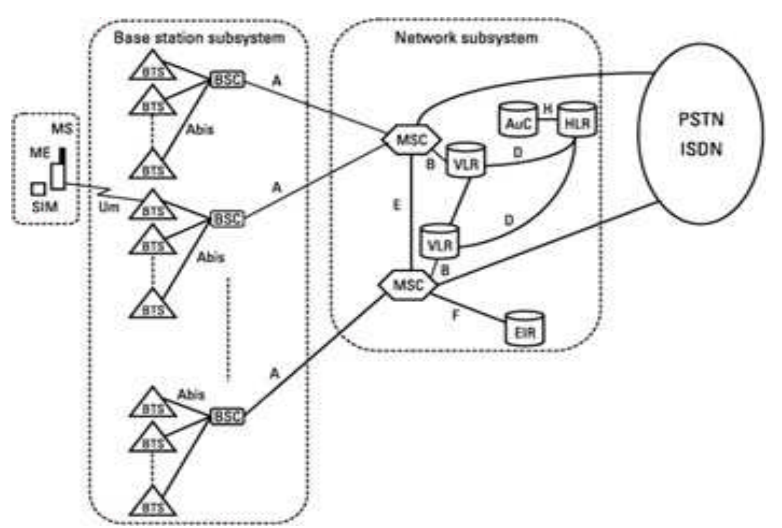

Gambar 2. Arsitektur umum dari jaringan GSM[6].

1. Mobile Stations(MS), terminal genggam.

2. Base station subsystem (BSS), yang mengontrol hubungan radio dengan MS;

3. Network and switching subsystem (NSS), yang mengelola fungsi koneksi beralih ke jaringan publik lainnya tetap atau pelanggan jaringan selular, dan menangani database yang diperlukan untuk manajemen mobilitas dan untuk data pelanggan. Seperti yang bisa dilihat dari angka tersebut, dalam PLMN, akses radio bagian jaringan (BSS) secara logika terpisah dari jaringan inti (NSS), untuk mempermudah standarisasi fungsi yang berbeda. (Seurre dkk, 2003).

\subsubsection{Mobile Stations (MS)}

Mobile Stations (MS) terdiri dari Mobile Equipmen (ME), dan SIM. Ini melakukan fungsifungsi berikut:
1. Radio transmisi dan penerimaan.

2. Sumber dan channel coding dan decoding, modulasi dan demodulasi sinyal.

3. Fungsi audio (amplifier, mikrofon, earphone).

4. Protokol untuk menangani fungsi radio : kontrol daya, frekuensi hopping, aturan untuk akses ke media radio.

5. Protokol untuk menangani call control dan mobilitas.

6. Keamanan algoritma (teknik enkripsi).

SIM memungkinkan pengguna untuk memiliki akses ke layanan berlangganan terlepas dari terminal tertentu. Penyisipan dari kartu SIM ke terminal manapun GSM memungkinkan pengguna untuk menerima panggilan pada terminal itu, untuk membuat panggilan dari terminal itu, dan untuk menggunakan layanan berlangganan lain. ME diidentifikasi dengan International Mobile Equipment Identity (IMEI).

Kartu SIM berisi, di antara informasi lain, International Mobile Subscriber Identity (IMSI) yang digunakan untuk mengidentifikasi pelanggan ke sistem, dan kunci rahasia untuk otentikasi. IMEI dan IMSI adalah independen, sehingga memungkinkan mobilitas pribadi [6].

\subsubsection{Kelas-kelas GPRS MS (Mobile Station)}

GPRS telah didefinisikan dalam Tiga kelas yaitu: kelas A, kelas B, dan kelas C. Kelas Sebuah ponsel dapat mendukung secara bersamaan komunikasi di sirkuit mode switched dan satu lagi di paket-mode switched. Hal ini juga mampu mendeteksi dalam modus siaga panggilan masuk di sirkuit atau paket-mode switched.

Kelas B mobile dapat mendeteksi panggilan masuk dalam mode circuit-switched atau dalam modus packet-switched pada modus siaga tetapi tidak dapat mendukung mereka secara bersamaan. Panggilan sirkuit dan paket dilakukan secara berurutan. Dalam beberapa konfigurasi yang diinginkan oleh pengguna, komunikasi GPRS dapat ditangguhkan dalam rangka untuk melakukan komunikasi dalam circuit-switched mode dan kemudian dapat dilanjutkan setelah rilis komunikasi dalam circuit-switched mode.

Kelas $\mathrm{C}$ mendukung mobile baik komunikasi dalam circuit-switched mode atau dalam paketswitched mode namun tidak mampu secara bersamaan mendukung komunikasi di kedua mode. Hal ini tidak mampu mendeteksi secara bersamaan panggilan masuk dalam circuitswitched dan packet-switched mode selama modus siaga. Jadi ponsel kelas $\mathrm{C}$ dikonfigurasi 
baik dalam circuit-switched mode atau dalam modus paket-switched. Konfigurasi mode yang dipilih secara manual oleh pengguna atau secara otomatis oleh aplikasi.

Sebuah mobile didefinisikan dalam kelas B kelas A atau IMSI terlampir untuk layanan GPRS, dan non-GPRS layanan sementara mobile didefinisikan dalam kelas $\mathrm{C}$ adalah IMSI terpasang jika beroperasi di circuit-switched mode atau IMSI terlampir untuk layanan GPRS jika beroperasi di dalam paket -switched mode. (Catatan: Sebuah MS yang IMSI berarti melekat yang terpasang ke jaringan GSM) [6].

\subsection{Hubungan Client-Server}

GPRS paket-transmisi modus bergantung pada klien / server prinsip dari dunia komputer, bukan memanggil / disebut prinsip yang digunakan dalam domain telepon. Klien mengirimkan permintaan ke server, yang proses permintaan dan mengirimkan hasilnya ke klien. Jadi ponsel mungkin dikonfigurasi sesuai dengan aplikasi baik dalam mode client atau dalam mode server.

Mobile dapat dikonfigurasi dalam mode client untuk memiliki akses ke Internet atau intranet atau database dengan memulai komunikasi GPRS. Biasanya, GPRS mobile dikonfigurasi sebagai klien. Gambar 3.3 menunjukkan sebuah mobile station (MS) GPRS dikonfigurasikan dalam mode client. Seperti pada Gambar 3.

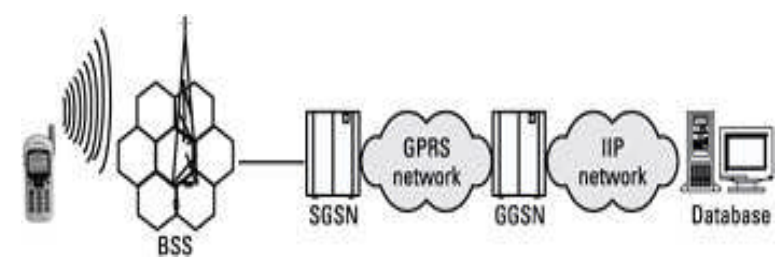

Gambar 3 GPRS mobile dikonfigurasi sebagai klien [6].

Mobile juga dapat dikonfigurasikan dalam mode server untuk aplikasi vertikal untuk pemantauan telemetri. Pada jenis aplikasi ini, ponsel dapat dihubungkan ke bagian yang berbeda dari peralatan, seperti kamera untuk memantau atau penculiknya untuk pengukuran. Mobile dapat mengkonfigurasi sebuah peralatan untuk memproses permintaan tersebut dan kemudian mengirim kembali hasilnya ke klien. Dalam rangka untuk menafsirkan permintaan dari klien, mobile harus dapat informasi rute dari jaringan ke aplikasi penerima. Dalam mode server, MS harus IMSI terlampir untuk layanan
GPRS agar dapat menerima permintaan dari klien [6].

\subsection{Kualitas Layanan}

Asosiasi jaringan kualitas tertentu layanan (QoS) dengan masing-masing transmisi data dalam modus paket GPRS. QoS yang tepat ini ditandai menurut sejumlah atribut dinegosiasikan antara mobile station (MS) dan jaringan. Gambar 3.4 ciri aplikasi dalam hal toleransi kesalahan dan persyaratan penundaan. Seperti pada Gambar 4 [6].

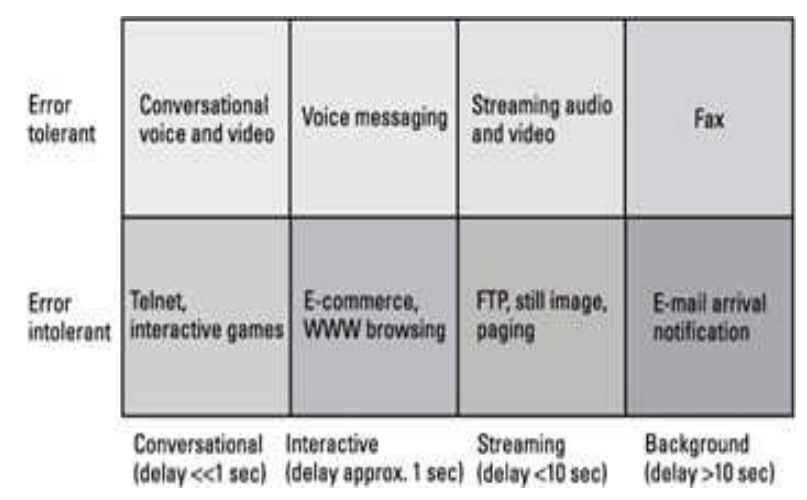

Gambar 4 Aplikasi dalam hal persyaratan QoS [6].

\subsection{Pendekatan Pelacakan (Tracking)}

Obyek/benda bergerak yang dibatasi oleh jaringan jalan dan mampu mengetahui posisi mereka jika dihubungkan oleh GPS penerima yang terkait. Obyek bergerak, yang disebut juga klien akan mengirimkan informasi lokasi mereka ke database pusat, yaitu server, melalui jaringan komunikasi nirkabel (Wireless). Maka yang menghubungkan antara klien dan server yang akan ditangani oleh mekanisme lain yaitu jaringan yang ada pada teknik pelacakan (Tracking). Ketika terjadi terputusnya koneksi, mekanismenya bahwa akan memberitahukan ke server kemudian akan di ambil tindakan yang sesuai. Setiap perubahan yang terjadi pada obyek bergerak, database akan menginformasikan obyek bergerak sebagai representasi atau fungsi prediksi, untuk menggunakan obyek posisi. Pada saat obyek bergerak terjadi perubah dan ketika posisi diprediksi menyimpang dari posisi sebenarnya maka informasi akan diperoleh dari GPS receiver. Maka digunakan pendekatan berbasis shared prediksi untuk melakukan tracking. Gambar 5 menyajikan kegiatan diagram UML untuk pendekatan dalam Tracking (aktivitas model diagram aktifitas perubahan obyek). Seperti pada Gambar 5 [7]. 


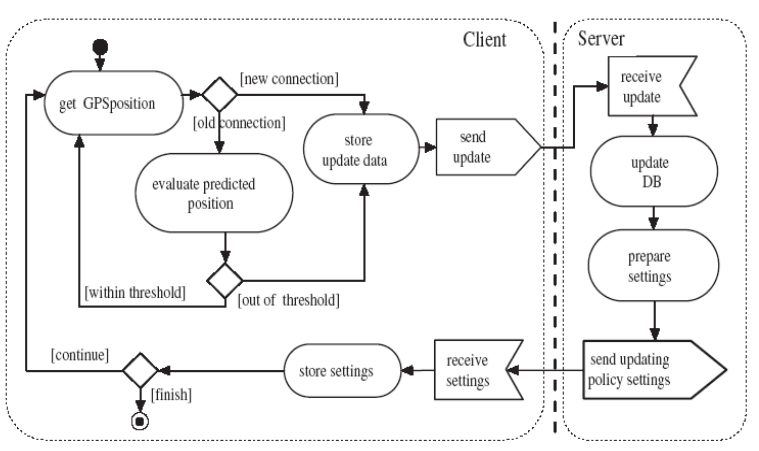

Gambar 5 Diagram skenario pelacakan [7].

\subsubsection{Teknik dasar tracking}

Menurut Wolfson dan Yin bahwa terdapat 3 jenis teknik dasar dalam pelacakan (tracking).

\subsubsection{Pelacakan berbasis Point (Point-based}

\section{Tracking)}

Dengan menggunakan teknik ini, Reprensetasi server sebuah masa depan merupakan posisi obyek sebagai yang paling baru-baru ini melaporkan posisi. Sebuah perubahan dikeluarkan oleh obyek ketika yang jarak dilaporkan sebelumnya menyimpang posisi dari posisi GPS dengan yang ditentukan ambang batas. Dengan demikian, pergerakan sebuah obyek direpresentasikan sebagai "titik melompat." Ini teknik yang paling primitif di antara teknik yang disajikan, tetapi juga mungkin cocok untuk gerakan yang tidak menentu, atau tidak diarahkan, sehubungan dengan ambang digunakan. Contohnya adalah pelacakan dengan ambang batas $200 \mathrm{~m}$ anak-anak yang bermain sepak bola [7].

\subsubsection{Pelacakan berbasis vektor (Vector-based Tracking)}

Dalam pelacakan berbasis vektor, posisi masa depan benda yang bergerak diberikan oleh linier fungsi dari waktu, yaitu, dengan posisi awal dan vektor kecepatan. Point berbasis pelacakan kemudian sesuai dengan kasus khusus dimana vektor kecepatan adalah vektor nol.

Sebuah penerima GPS baik menghitung kecepatan dan menuju obyek itu Associated dengan vektor kecepatan yang digunakan dalam representasi ini dihitung dari dua. Dengan menggunakan teknik ini, pergerakan sebuah obyek direpresentasikan sebagai jump vektor, pelacakan berbasis vektor mungkin berguna untuk menelusuri sebuah obyek. Algoritma PV (Prediksikan dengan Vektor) memprediksi lokasi obyek mo diberikan pada waktu $t$ diberikan [7].

\subsubsection{Segment-based Tracking}

Dalam hal ini yang menjadi gagasan utama adalah dengan memanfaatkan pengetahuan tentang jaringan jalan dimana obyek bergerak. Dengan tersedianya sebuah digital yang merepresentasikan dari jaringan jalan sangat diperlukan. Server menggunakan informasi lokasi GPS yang diterimanya dari obyek untuk mencari obyek dalam jaringan jalan. Hal ini dilakukan dengan cara pencocokan peta, yang merupakan teknik yang posisi obyek pada segmen jaringan jalan, ditetapkan sebagai jarak dari awal segmen itu, berdasarkan informasi lokasi dari penerima GPS [7].

\section{HASIL DAN PEMBAHASAN}

Sistem yang dibuat untuk menangani penambahan, pengurangan, dan perubahan pada poi. Dinamisnya poi mengharuskan adanya seseorang atau seoarng pengelola yang khusus menangani perubahan-perubahan tersebut. Maka, sistem yang dibuat dibedakan atas dua pengguna yaitu admin dan public user/user umum. Admin berhak melakukan administrasi pada poi (point of interest). Admin bersifat tertutup, membutuhkan verifikasi untuk masuk ke dalam sistem. Admin berhak mengubah, manambah atau menghapus data yang ada. Sedangkan public user/user umum hanya dapat data poi melalui mobile untuk menambahkan poi ke sebuah website.

3.1 Menu utama pada gps tracking pada kendaraan dan untuk user public

Pada menu utama data input pada aplikasi GPS tracking mobile digunakan oleh user public/pemilik kendaraan, yaitu berfungsi untuk input poi / kendaraan berada. Dalam hal ini menggunakan input poi AB.8865.HK dan memasukkan url dalam hal ini penulis menggunakan alamat website http://maptrack.uk.cm/ getgooglemap2.php, url tersebut berfungsi untuk meng-isertkan posisi poi, dapat juga mengatur update map setiap 1 menit ataupun 10 menit. Seperti pada Gambar 6.

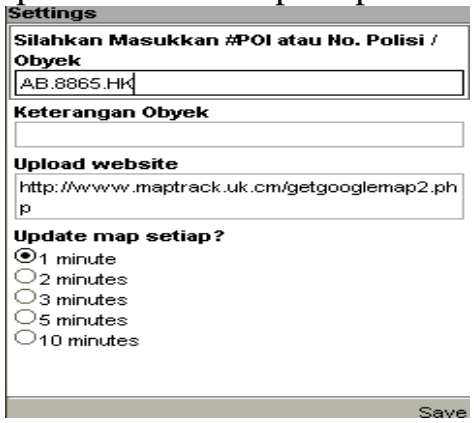

Gambar 6 Tampilan input pada aplikasi mobile 
Setelah public user/pemilik kendaraan menginputkan poi AB.8865.HK, seperti pada Gambar 7, kemudian pilih tombol save berfungsi untuk proses insert poi, seperti pada Gambar 6.1. maka setalah disave (disimpan), maka akan ditampilkan proses insert pada posisi berada, seperti pada Gambar 7.

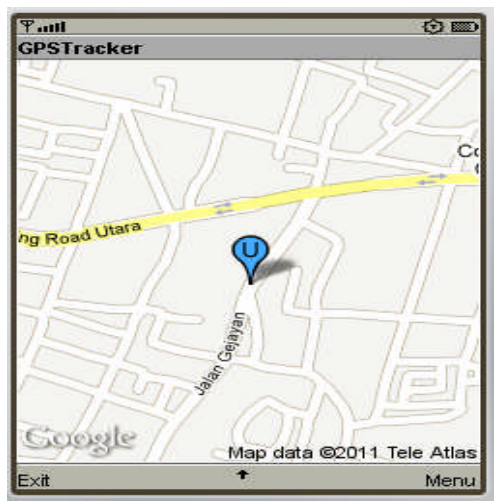

Gambar 7 Tampilan posisi kendaraan dengan nomor polisi AB.8865.HK dengan googlemap pada mobile

Dari Gambar 7 posisi awal kendaraan dengan nomor polisi AB.8865.HK berada, dan terjadi perubahan posisi setelah ada perubahan tempat pada kendaraan dengan nomor polisi AB.8865.HK. Sepert pada Gambar 8.

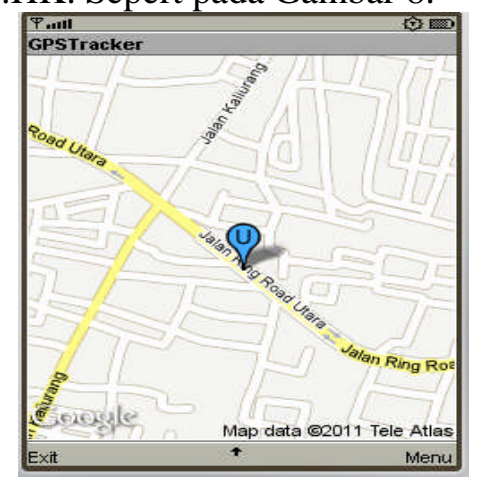

Gambar 8 Tampilan perubahan posisi kendaraan dengan nomor polisi AB.8865.HK dengan googlemap pada mobile

\subsection{Pembacaan informasi dari GPS}

Data posisi dikirim dari GPS receiver yaitu dalam format NMEA-0183 tipe RMC. Pada penelitian ini data yang diterima di smartphone tidak selamanya lengkap. Seperti sebagai berikut: Contoh data lengkap :

\$GPGSV,21,07,02,32,123,,25,14,208,,26,06,0

Contoh data tidak lengkap:

$$
\mathrm{A}, 1,,,,,,,,,,,,,, 32
$$

Pada pembacaan data yang lengkap akan menghasilkan informasi posisi dengan baik, apabila pembacaan data yang kurang lengkap akan menghasilkan infomasi yang kurang baik, hal ini dikarenakan cuaca yang kurang mendukung, sistem yang dibangun juga belum stabil dan belum lengkap seperti fasilitas pencarian obyek pada pada mobile, fasilitas navigasi belum ada. Pada sistem ini telah dilakukan uji coba mengakses ke sistem dengan 5 user pada waktu yang bersamaan masih berjalan dengan baik, pada dasarnya sistem ini dapat melayani lebih dari 5 user yang mengakses secara bersamaan, dan sistem ini pada dasarnya bisa atau tidak tidaknya melayani user lebih dari 5 user yaitu ada pada bandwidth (signal processing) yang ada pada server, semakin besar bandwidth semakin baik dalam melayani pengaksesan yang diminta oleh user.

\subsection{Hasil pengiriman data posisi ke server}

Berdasarkan hasil penelitian yang dilakukan dengan pengaturan interval pengiriman data dari smartphone adalah per 1 menit, data yang didapatkan dari pengiriman data ke server terjadi delay hanya beberapa detik, data yang dikirm ke server meliputi gpslocationid, lastupdate, latitude, longitude, poi, speed, direction, distance, gpstime, locationmethod, accuracy, seperti pada contoh data poi AB.8865.HK dengan jam 13:46:16 dan 13:48:20, hal ini terjadi delay dikarenakan koneksi GPRS nya terganggu dengan cuaca dan juga bandwith dari server terbatas akibatnya server lambat dalam merespon data yang dikirim oleh user melalui smartphone, seperti pada Tabel 1 .

Tabel 1 Hasil pengiriman data posisi ke server

\begin{tabular}{|c|c|c|c|c|}
\hline $\begin{array}{c}\text { GPSLoc } \\
\text { ationID }\end{array}$ & LastUpdate & Latitude & Longitude & poi \\
\hline 29 & $\begin{array}{c}2010-09-17 \\
13: 46: 16\end{array}$ & -7.761156 & 110.394267 & $\begin{array}{c}\text { AB.8865. } \\
\text { HK }\end{array}$ \\
\hline 30 & $\begin{array}{c}2010-09-17 \\
13: 48: 20\end{array}$ & -7.758764 & 110.395576 & $\begin{array}{c}\text { AB.8865. } \\
\text { HK }\end{array}$ \\
\hline 31 & $\begin{array}{c}2010-09-17 \\
13: 50: 33\end{array}$ & -7.758764 & 110.394868 & $\begin{array}{c}\text { AB.8865. } \\
\text { HK }\end{array}$ \\
\hline 32 & $\begin{array}{c}2010-09-17 \\
13: 52: 33\end{array}$ & -7.759253 & 110.392765 & $\begin{array}{c}\text { AB.8865. } \\
\text { HK }\end{array}$ \\
\hline
\end{tabular}

Untuk hasil yang diinsertkan dari gps tracking pada mobile oleh pubic user, akan ditampilkan pada website, seperti pada Gambar 9. 


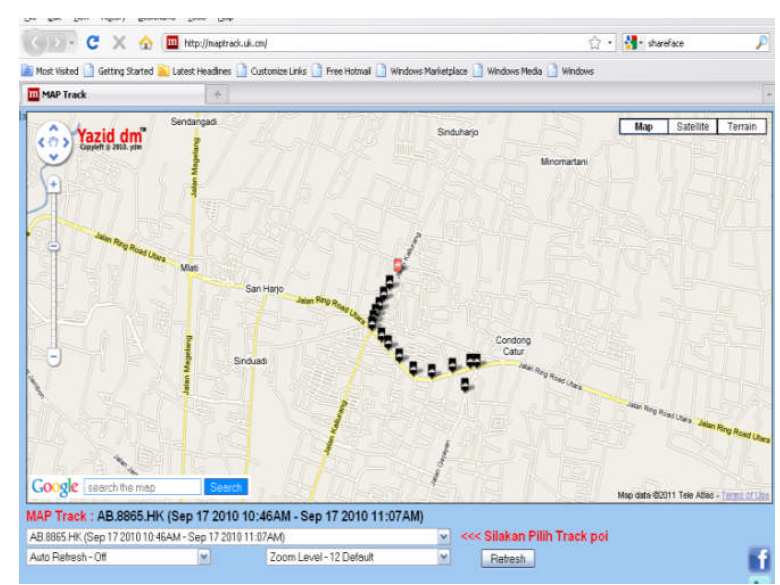

Gambar 9 Tampilan hasil website dari tracking pada mobile dengan poi AB.8865.HK

Infomasi pada hasil yang diinsertkan dari gps tracking pada mobile oleh pubic user yang ditampilkan pada website mempunyai informasi posisi poi, yaitu dengan cara mengklik pada waypoint, seperti pada Gambar 10.

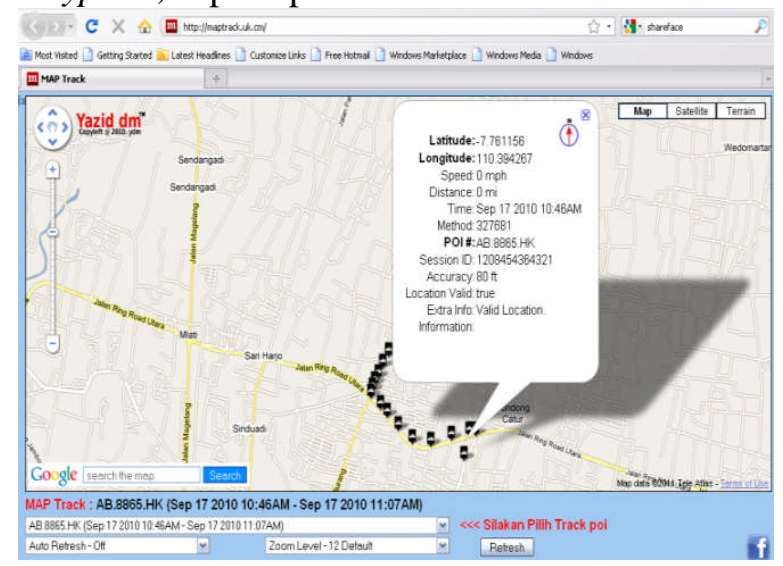

Gambar 10 Tampilan informasi hasil website dari tracking pada mobile dengan poi AB.8865.HK

\section{KESIMPULAN}

Telah dibangun sebuah sistem pelacakan kendaraan bermotor menggunakan gps dan gprs dengan integrasi googlemap.

1. Sistem pelacakan kendaraan bermotor menggunakan gps dan gprs dengan integrasi googlemap yang dibuat sesuai tujuan yaitu mampu memonitoring secara terus menerus pergerakan kendaraan bermotor.

2. Sistem pelacakan kendaraan bermotor menggunakan gps dan gprs dengan integrasi googlemap ini memanfaatkan gps receiver berupa latitude dan longitude, kemudian diparsing ke website melalui koneksi GPRS, dan data posisi yang dikirim dari GPS receiver dalam format NMEA-0183.
3. Sistem pelacakan kendaraan bermotor menggunakan gps dan gprs dengan integrasi googlemap memanfaatkan googlemap untuk menampilkan waypoint yang ada pada peta.

4. Sistem yang dibangun sudah bersifat dinamis sehingga pengeditan/perubahan data dapat dilakukan apabila ada perubahan obyek dapat segera dilakukan oleh administrator.

5. Sistem yang dibangun telah menyediakan fasilitas pencarian posisi obyek dan menampilkan posisi obyek, fasilitas ini hanya terdapat pada website.

6. Sistem yang dibangun khususnya pada mobile belum adanya fasilitas pencarian obyek dan belum adanya fasilitas navigasi untuk menampilkan obyek yang terdapat mobile.

\section{SARAN}

Saran yang dapat diberikan dari hasil pembuatan sistem pelacakan kendaraan bermotor menggunakan gps dan gprs dengan integrasi googlemap adalah sebagai berikut :

1. Perlunya informasi routing dengan menunjukkan nama jalan untuk jalur hasil routingnya dan nomor polisi.

2. Masih perlunya sistem yang terintegrasi ke berbagai instansi yang terkait seperti kepolisian, asuransi, kantor pajak, dan lain-lain, supaya apabila terjadi hal-hal tidak diinginkan seperti terjadi pencurian kendaraan, maka sistem dapat mengirimkan informasi ke pihak kepolisian secara otomatis supaya dari pihak kepolisian lebih cepat melacak dan mengusut, dan bisa juga mengirimkan informasi ke asuransi apabila kendaraan yang dicuri itu sudah di asuransikan. Dan supaya lebih mudah apabila dalam pengurusan / meng-klaim asuransi.

3. Sistem yang telah dibuat untuk pengembangan kedepannya, supaya pada aplikasi mobile diberikan fasilitas pencarian, navigasi, dan fasilitas informasi tempat ataupun jalur terpendek.

4. Masih diperlukannya fasilitas untuk SMS pada aplikasi mobile, apabila terjadi lost contact seperti gangguan dalam dalam koneksi GPRS, supaya sistem tetap berkerja dalam pengiriman data ke server. 
5. Masih diperlukannya teknologi pencarian pada mobile dan didukung sistem pendukung keputusan untuk mendapatkan informasi pencarian kendaraan yang lebih komplek dalam pencarian dan penanganan terutama pada pencatatan data kendaraan yang lebih lengkap dan detail.

6. Sistem yang telah dibuat untuk pengembangan lebih lanjut, supaya ditambahkan teknologi A-GPS, agar dalam pengiriman data ataupun pendeteksian posisi dapat lebih akurat.

\section{DAFTAR PUSTAKA}

[1] Egenhofer, M., 1992, “Why Not SQL!', International Journal of Geographical Information System.

[2] Li, L., Li, C. and Lin, Z., 2002, "Investigation on The Concept Model of Mobile GIS", Symposium on Geospatial Theory, Processing and Applications, Ottawa.

[3] Winardi., 2001, "Penentuan Posisi dengan GPS untuk Survei Terumbu Karang", Puslit Oceanografi - LIPI, Jakarta.

[4] Leick, A., 2004, "GPS Satellite Surveying”, third edition, John Wiley \& Sons, Inc., Hoboken, New Jersey.

[5] French., G.T., 1996, Understanding The GPS "An Introduction To the Global Positioning System", First Edition, GeoResearch, Inc, Bethesda, MD, United States of America.

[6] Seurre, E, Savelli, P. and Pietri, J., 2003, "GPRS for Mobile Internet", Artech House. MA. United States of America.

[7] Civilis, A, Jensen, C.S, Nenortaite, N. and Pakalnis, S., 2004," Efficient Tracking Of Moving Objects With Precision Guarantees", http://www.springer.com/978-3-540-69877-7, diakses pada tanggal 20 juni 2010. 